\title{
AKIBAT HUKUM PEMALSUAN SURAT OLEH KEPALA DESA (Studi Kasus Putusan Nomor 60/PID.B/2013/PN.Unh)
}

\author{
Oleh \\ Joejoen Tjahjani \\ Dosen Fakultas Hukum Universitas Islam Lamongan
}

\begin{abstract}
Abstrak
Pemalsuan surat merupakan suatu bentuk tindak pidana yang terdapat dalam BUKU II BAB XII KUHP yang menyatakan bahwa '(1) Barang siapa membuat surat palsu atau memalsukan surat, yang dapat menerbitkan suatu hak, sesuatu perjanjian (kewajiban) atau sesuatu pembebasan utang atau yang boleh dipergunakan sebagai keterangan bagi suatu perbuatan, dengan maksud akan menggunakan atau menyuruh orang lain menggunakan surat-surat itu seolah-olah surat itu asli dan tidak dipalsukan, maka kalau mempergunakannya dapat mendatangkan suatu kerugian dihukum karena pemalsuan surat, dengan hukuman penjara selama-lamanya enam tahun." Akibat hukum dari memalsu surat adalah dapat menimbulkan kerugian. Kata "dapat" maksudnya tidak perlu bahwa kerugian itu harus nyata atau benarbenar ada, baru kerugian itu sudah cukup untuk menjerat pelaku pemalsu surat itu. Surat adalah segala surat baik yang ditulis dengan tangan, dicetak, maupun diketik atau ditulis menggunakan mesin tik, dan lain-lain. Salah satu contoh dari pemalsuan surat adalah yang dilakukan oleh Kepala Desa Amboniki sebagaimana yang tercantum dalam putusan Mahkamah Agung Nomor 60/ Pid.B/ 2013/ PN.Unh. Hakim dalam menjatuhkan putusan menganut beberapa teori antara lain : Sistem atau teori pembuktian berdasarkan Undangundang secara positif, sistem atau teori pembuktian berdasarkan keyakinan hakim melulu, sistem atau teori pembuktian berdasar keyakinan hakim atas alasan yang logis, dan sistem atau teori pembuktian berdasarkan Undang-undang secara negatif.
\end{abstract}

Kata Kunci : Akibat hukum, Kepala Desa.

\section{A. Pendahuluan}

\section{- Latar Belakang}

Semakin hari peradaban dunia seakanakan berlomba menuju kearah modernisasi yang selalu membawa perubahan dalam berbagai sendi kehidupan yang mana perubahan tersebut terlihat tampak sangat nyata. Peradaban perkembangan itu juga selalu diikuti dengan berbagai bentuk kejahatan yang menjadikan terjadinya pelanggaran atau penyimpangan terhadap hukum dan norma yang berlaku. Salah satu bentuk pelanggaran atau penyimpangan terhadap hukum dan undang-undang tersebut yang sering terjadi di lingkungan masyarakat adalah seperti pemalsuan surat.

Tindak pidana pemalsuan surat merupakan salah satu bentuk kejahatan yang sering terjadi di lingkungan masyarakat, yang mana pelaku dari tindak pidana tersebut adalah orang atau sekelompok orang yang mempunyai jabatan, seperti : kepala sekolah, Kepala Desa maupun pejabat lain yang mempunyai suatu jabatan di lingkungan masyarakat itu.

Surat adalah lembaran kertas yang diatasnya terdapat tulisan kata, frasa, dan/ atau kalimat yang terdiri dari huruf-huruf atau angka dalam bentuk apapun dan dibuat dengan cara apapun yang tulisan mana mengandung arti dan/ atau makna buah pikiran manusia. Kebenaran mengenai arti dan /atau makna tersebut harus mendapat perlindungan hukum. Sebagai suatu pengungkapan dari buah 
pikiran tertentu yang terdapat di dalam surat harus mendapat kepercayaan masyarakat. Dibentuknya tindak pidana pemalsuan surat ini ditujukan bagi perlindungan hukum tehadap kepercayaan masyarakat terhadap kebenaran mengenai isi surat-surat tersebut. Tindak pidana pemalsuan surat ini dibentuk untuk memberi perlindungan hukum terhadap kepercayaan yang diberikan oleh umum (publica fides) pada surat. ${ }^{12}$

Ada beberapa perbuatan yang termasuk ke dalam jenis pemalsuan surat, seperti pemalsuan tanda tangan maupun cap atau stempel yang merupakan salah satu bentuk dari kejahatan pemalsuan surat. Pemalsuan tanda tangan merupakan salah satu bentuk kejahatan yang masih kurang dipahami atau sesuatu yang masih awam untuk dimengerti oleh masyarakat terutama mengenai dampak yang akan timbul dikemudian hari sebagai akibat dari kejahatan pemalsuan tanda tangan tersebut. Masyarakat yang masih kurang paham akan dampak dari pemalsuan tanda tangan terkadang berasumsi bahwa memalsukan tanda tangan adalah cara yang paling efisien disaat mereka terdesak oleh waktu yang ada, sedangkan tanda tangan tersebut sangat dibutuhkan oleh mereka. Mereka berasumsi bahwa hal tersebut mereka lakukan karena sudah sangat terdesak oleh waktu. Namun alasan apapun sebenarnya sangat tidak dibenarkan. Karena bagaimanapun juga kejahatan pemalsuan tanda tangan merupakan suatu tindak pidana yang bertentangan dengan norma hukum maupun Undang-undang yang berlaku.

Keadaan palsu atau tidak benar sutau tulisan atau berita yang diucapkan atau disebarkan dapat membawa pengaruh terhadap aspek kehidupan. Oleh karena itu,

\footnotetext{
${ }^{12}$ Adami Chazawi dan Ardi Ferdian. Tindak Pidana Pemalsuan (Tindak Pidana yang Menyerang Kepentingan Hukum Terhadap Kepercayaan Masyarakat Mengenai Kebenaran Isi Tulisan yang Disampaikan). PT RajaGrafindo Persada. Jakarta. 2016. H. 135.
}

isi tulisan atau berita dalam kedaan tertentu atau dengan syarat-syarat tertentu tidak boleh mengandung sifat palsu. Sifat palsu dari isi tulisan atau berita yang mengandung pengaruh buruk itulah yang perlu dihindari, dengan cara mengancam pidana bagi perbuatan yang membuat, menyampaikannya. Istilah pemalsuan, tidak perlu selalu diartikan pada perbuatan yang menjadikan palsunya isi tulisan seperti surat atau sejenisnya, melainkan termasuk juga palsunya isi berita / informasi yang tidak dituliskkan seperti diucapkan atau disampaikan secara verbal. $^{13}$

\section{B. Pembahasan}

* Unsur dari Delik Pemalsuan Surat

Tindak pidana pemalsuan surat terdapat dalam pasal 263 KUHP BAB XII buku II yang berbunyi:

"(1) barang siapa membuat surat palsu atau memalsukan surat, yang dapat menerbitkan suatu hak, sesuatu perjanjian atau sesuatu pembebasan hutang, atau yang boleh dipergunakan atau menyuruh orang lain mempergunakan surat-surat itu seolah-olah surat itu asli dan tidak di palsukan, maka kalau memeprgunakanya dapat mendatangkan sesuatu kerugian dihukum karena pemalsuan surat, dengan hukuman penjara selama-lamanya enam tahun". "(2) dengan hukuman serupa itu juga dihukum, barang siapa dengan sengaja menggunakan surat palsu atau yang di palsukan itu seolah-olah surat itu asli dan tidak dipalsukan, kalau hal mempergunakan dapat mendatangkan sesuatu kerugian".

Dari pasal tersebut, kita bisa mengetahui bahwa unsur dari delik pemalsuan surat

\footnotetext{
${ }^{13}$ Ibid. H. 6
} 
ada dua, yakni unsur obyektif dan unsur subyektif.

\section{Unsur obyektif meliputi:}

a. Perbuatannya.

(1) Membuat surat palsu;

Membuat surat palsu adalah membuat surat yang yang isinya bukan semestinya (tidak benar), atau membuat surat demikian rupa, sehingga menunjukkan asal surat itu yang tidak benar.

Palsunya sebuah surat tidak hanya terletak pada isi dari surat, bisa juga palsunya surat tersebut dikarenakan adanya tanda tangan yang di buat oleh si pembuat surat yang mana tanda tangan tersebut seolah-olah asli dan ditandatangani oleh orang yang nama sebenarnya ada dalam surat tersebut.

Pemalsuan surat mengenai nama dan tanda tangannya ini ada dua macam $:^{14}$

Pertama, membuat dengan meniru tanda tangan seseorang yang sesungguhnya tidak ada orang yang mempunyai nama tersebut, atau tidak diketahui siapa orangnya. Nama orang ini dibuat fiktif atau dikarang-karang saja.

Kedua, membuat surat dengan menggunakan nama orang lain yang dikenal- tanpa sepengetahuan atau persetujuan si pemilik nama tersebut. Kemudian si pembuat surat membubuhkan tanda tangan orang itu dengan meniru atau seolah-olah tanda tangan tersebut merupakan tanda orang yang namanya dicantumkan dalam surat itu.

\footnotetext{
${ }^{14}$ Adami Chazawi dan Ardi Ferdian. Tindak Pidana Pemalsuan (Tindak Pidana yang Menyerang Kepentingan Hukum Terhadap Kepercayaan Masyarakat Mengenai Kebenaran Isi Tulisan yang Disampaikan). PT RajaGrafindo Persada. Jakarta. 2016. H. 139.
}

Tanda tangan yang dimaksud di sini adalah termasuk tanda tangan dengan menggunakan cap/stempel tanda tangan. Begitu juga tanda tangan dengan menggunakan mesin "scanner". Tanda tangan seperti itu bukanlah termasuk tanda tangan palsu, dan orang yang menggunakan cap/ stempel tanda tangan atau menempatkan tanda tangan dengan mesin scanner bukan termasuk perbuatan meniru tanda tangan orang lain, dan bukanlah termasuk membuat surat palsu sebagaimana dalam pasal 263 ayat (1). Alasannya, karena orang yang menggunakan cap/stempel tanda tangan atau dengan mengguanakan mesin scanner membubuhkan tanda tangan bukan miliknya dia atas surat tersebut, telah mendapat perintah atau persetujuan orang yang sebenarnya memiliki tanda tangan. Apabila syarat ini tidak dipenuhi, maka tanda tangan tersebut termasuk tanda tangan palsu, dan orang yang mengguanakan stempel tanda tangan atau mesin scanner tersebut dapat di pidana karena melanggar pada pasal 263 ayat (1). ${ }^{15}$

\section{(2) Memalsu}

Mengubah surat demikian rupa, sehingga isinya menjadi lain dari isi yang asli, atau sehingga surat itu menjadi lain dari yang asli. Adapun caranya bermacam-macam, tidak senantiasa perlu bahwa surat itu diganti dengan yang lain. Dapat pula dilakukan dengan jalan mengurangkan, menambah atau merubah sesuatu dari surat itu.

b. Obyeknya

(1) Surat yang dapat menimbulkan suatu hak.

Surat yang berisi suatu perikatan pada dasarnya adalah berupa surat yang karena perjanjian yang tertulis dalam surat itu melahirkan hak tertentu. Hak dapat lahir dari perjanjian jual beli, tukar menukar, sewa menyewa dan sebagainya yang dituliskan dalam sebuah surat. Misalnya surat jual beli,

\footnotetext{
${ }^{15}$ Ibid. H. 140
} 
melahirkan hak pembeli untuk menerima barang yang dibelinya dan hak untuk memilikinya. Bagi penjual melahirkan hak untuk menerima pembayaran sejumlah harga barang yang diperjual belikan. ${ }^{16}$

(2) Surat yang menimbulkan suatu perikatan.

Perikatan yang dimaksud dalam pasal 263 ayat (1) adalah semua bentuk perikatan yang ada dalam hukum perikatan, baik perikatan yang lahir karena perjanjian maupun perikatan yang lahir karena undangundang sebagaimana diatur dalam KUHPerdata. ${ }^{17}$

(3) Surat yang dapat menimbulkan suatu pembebasan hutang.

Jenis surat yang menjadi objek pemalsuan surat dalam pasal 263 ayat(1) yang ketiga ialah surat yang membebaskan hutang atau surat surat yang menimbulkan pembebasan hutang. Membebaskan hutang artinya menghapus kewajiban hukum untuk membayar atau menyerahkan sejumlah uang. Jadi hutang tidak selamanya harus diartikan sebagai perbuatan hukum hutang-piutang (objeknya uang). ${ }^{18}$

(4) Surat yang diperuntukkan sebagai bukti bagi suatu hal.

(5) Ada dua hal yang penting untuk dibicarakan dalam kalimat pendek tersebut, ialah: ${ }^{19}$

Pertama, Pengertian mengenai diperuntukkan sebagai bukti;

Kedua, pengertian mengenai "suatu hal".

Arti bukti ialah bahwa surat itu mempunyai nilai pembuktian atau kekuatan pembuktian (bewijskracht). Sebuah surat yang demikian itu karena sifatnya mempunyai nilai pembuktian

\footnotetext{
${ }^{16}$ Ibid. H. 145

${ }^{17}$ Ibid. H. 146

${ }^{18}$ Ibid.

${ }^{19}$ Ibid. H. 147.
}

mengenai isinya. Siapa yang menentukan adanya nilai pembuktian mengenai sesuatu hal dalam surat itu? Dalam hal ini bukan pembuat surat yang menentukan nilai pembuktian itu, melainkan undang-undang atau kekuasaan tata usaha negara (administratief gezag). ${ }^{20}$

Sedangkan kekuatan pembuktian atas surat-surat oleh kekuasaan tata usaha negara, misalnya buku kas, rekening koran atau rekening giro dalam suatu bank, surat kelakuan baik, KTP, surat angkutan, faktur, dan lain sebagainya. Oleh karena terdapat perkataan "diperuntukkan" dalam kalimat "diperuntukkan sebagai bukti bagi sesuatu hal", maka surat tersebut sengaja dibuat/ diterbitkan untuk membuktikan tentang kebenaran mengenai "sesuatu hal"- isinya surat tesebut. $^{21}$

c. Pemakaian surat tersebut dapat menimbulkan suatu kerugian;

Kerugian yang dapat atau mungkin timbul jika surat palsu atau dipalsu tersebut digunakan, tidak perlu diketahui atau disadari oleh si pembuat. $^{22}$

Tidak ada ukuran tertentu untuk menentukan adanya kemungkinan kerugian jika surat palsu atau surat yang dipalsu tersebut digunakan. Akibat timbulnya kerugian tersebut dapat dipikirkan oleh semua orang, ialah bila surat semacam itu digunakan dapat (potensia) menimbulkan kerugian. Bagi siapa yang menderita kerugian, tidak harus ditentukan orangnya, kerugian itu

\footnotetext{
${ }^{20}$ Ibid. Dikutip dari Satochid Kartanegara (I).

Diktat, Hukum Pidana II Delik-delik Tertentu. Balai Lektur Mahasiswa. Tanpa Tahun.

${ }^{21}$ Adami Chazawi dan Ardi Ferdian. Tindak Pidana

Pemalsuan (Tindak Pidana yang Menyerang

Kepentingan Hukum Terhadap Kepercayaan

Masyarakat Mengenai Kebenaran Isi Tulisan yang

Disampaikan). PT RajaGrafindo Persada. Jakarta. 2016. H. 148

22 Ibid. H. 151
} 
bagi siapa saja atau bagi kepentingan umum. $^{23}$

\section{Unsur subyektif:}

d. Kesalahan : dengan maksud untuk memakai atau menyuruh orang lain memakai seolah-olah isinya benar dan tidak dipalsukan.

Unsur kesalahan dalam tindak pidana membuat surat palsu atau memalsu surat tersebut, adalah berupa kesengajaan sebagi maksud (opzet als oogmerk) atau kesengajaan dalam arti sempit. Maksud si pembuat membuat surat palsu atau memalsu surat tersebut ditujukan untuk digunakan olehnya sendiri atau digunakan oleh orang lain. Sementara perbuatan menggunakan surat itu tidak perlu sudah diwujudkan. Sebab unsur maksud hanya dalam batin atau sikap batin si pembuat, yang harus sudah terbentuk sebelum melakukan perbuatan (in casu membuat palsu atau memalsu). Sikap batin ini harus dibuktikan, bukan penggunaannya yang harus dibuktikan. ${ }^{24}$

Bagaimana pembuktian unsur subjektif seperti kesengajaan, misalnya kesengajaan sebagai maksud dalam pasal 263 ayat (1) KUHP ini? Dalam pembuktian unsur sengaja yang dicantumkan dalam rumusan tindak pidana, perlu memperhatikan 3 hal, ialah: $:^{25}$

1. Hubungan sengaja dengan unsur lain dalam rumusan tindak pidana.

2. Semua keadaan ketika perbuatan dilakukan.

3. Kedaan dan kemampuan jiwa si pembuat ketika berbuat.

Oleh karena "maksud" itu adalah bagian dari kesengajaan (opzettelijk) maka dalam hal membuktikan unsur maksud juga

\footnotetext{
${ }^{23}$ Ibid. H. 152.

${ }^{24}$ Ibid. H. 153.

${ }^{25}$ Ibid. H. 154
}

perlu memerhatikan tiga hal tersebut.

\section{Akibat Hukum dari Delik Pemalsuan Surat dalam Putusan Nomor 60/ Pid.B/2013/PN.Unh.}

Bahwa oleh karena dakwaan Jaksa Penuntut Umum secara alternatif maka Majelis Hakim memilih dakwaan yang lebih tepat dengan tindak pidana yang dilakukan oleh terdakwa, dan menurut Majelis Hakim adalah tepat apabila terdakwa didakwa dengan dakwaan melanggar pasal 263 ayat (1) KUHP yang unsur-unsurnya sebagai berikut :

1. Unsur barang siapa;

2. Unsur membuat surat palsu atau memalsukan surat;

3. Unsur yang dapat menimbulkan suatu hak, perikatan atau pembebasan hutang, atau yang diperuntuntukkan sebagai bukti daripada sesuatu hal dengan maksud untuk memakai atau menyuruh orang lain memakai surat tersebut seolah-olah isinya benar dan tidak dipalsu, diancam jika pemakaian tersebut dapat menimbulkan kerugian, karena pemalsuan surat;

Kemudian unsurr-unsur tersebut diatas akan dipertimbangkan seprti di bawah ini:

\section{UNSUR BARANG SIAPA}

Menimbang bahwa yang dimaksud dengan barang siapa dalam unsur ini adalah ditujukan kepada subyek hukum yang dalam perkara ini adalah orang yang memiliki kecakapan untuk mempertanggung jawabakan secara hukum setiap perbuatan yang dilakukannya;

Menimbang, bahwa dipersidangan telah dihadapkan seorang laki-laki bernama ABD. MUIS BIN KAEMEETO yang identitasnya sama dan bersesuaian dengan surat dakwaan dan dalam persidangan tersebut dibenarkan oleh Terdakwa sendiri. 
Menimbang, bahwa selama proses persidangan terdakwa dinilai mampu mengikuti proses persidangan, mampu menjawab pertanyaan yang diajukan kepadanya, mampu memberikan pendapat dan keterangan dengan baik sehingga menunjukkan bahwa terdakwa dalam keadaan sehat jasmani dan rohani;

Menimbang, bahwa berdasarkan keterangan-keterangan tersebut diatas, maka Majelis Hakim menyimpulkan bahwa terdakwa adalah orang yang mampu mepertanggungjawabkan perbuatannya menurut hukum pidana, sehingga dengan demikian Majelis Hakim berpendapat bahwa unsur ini telah terpenuhi;

2. UNSUR MEMBUAT SURAT PALSU ATAU MEMALSUKAN SURAT

Menimbang bahwa membuat surat palsu berbeda dengan memalsu surat ;

Menimbang, bahwa telah terlebih dahulu dipertimbangkan makna surat;

Menimbang, bahwa yang diartikan dengan surat adalah segala surat baik yang ditulis dengan tangan, cetak maupun ditulis memakai mesin ketik dan lain-lain. Membuat surat palsu adalah membuat yang isinya bukan semestinya tidak benar atau membuat surat sedemikian rupa, sehingga menunjukkan asal surat itu yang tidak benar, sedang memalsu surat adalah mengubah surat sedemikian rupa, sehingga isinya menjadi lain dari isi yang asli. Bahwa memalsu tanda tangan masuk juga dalam pengertian memalsu surat;

Menimbang bahwa untuk membuktikan unsur ini Majelis Hakim perlu menggunakan fakta-fakta hukum sebagai berikut :

- Bahwa benar kejadiannya pada tanggal 27 Juni 2010 bertempat di Kel. Arombu Kec. Unaaha Kab. Konawe, terdakwa telah memalsukan tanda tangan saksi ABDUL RASYID dan saksi BASRAN;

- Bahwa benar isi proposal tersebut yang kesemuanya ada tanda tangan saksi ABDUL RASYID dan saksi BASRAN berupa :

1. Permohonan bantuan dana Block Grand;

2. Lembaran daftar usulan kegiatan pembangunan Desa tahun anggaran 2010;

3. Lembaran rencana pembangunan jangka menengah Desa;

4. Lembaran alokasi bantuan Desa Amboniki;

5. Lembaran daftar usulan kegiatan pembangunan Desa tahun anggaran 2010 tahap I Desa Amboniki;

6. Lembaran daftar ususlan kegiatan pembangunan Desa tahun anggaran 2010 tahap II Desa Amboniki;

7. Lembaran daftar ususlan kegiatan pembangunan Desa tahun anggaran 2010 tahap III Desa Amboniki;

8. Lembaran rencana alokasi bantuan dana bantuan keuangan Desa Kelurahan tahun 2010 tahap I Desa Amboniki;

9. Lembaran rencana alokasi bantuan dana bantuan keuangan Desa Kelurahan tahun 2010 tahap II Desa Amboniki;

10. Lembaran rencana alokasi bantuan dana bantuan keuangan Desa Kelurahan tahun 2010 tahap III Desa Amboniki;

11. Lembaran Berita Acara Musrembang Desa dalam menyusun RKP Desa Amboniki;

12. Lembaran daftar hadir musyawarah pembangunan Desa Amboniki tentang penggunaan Dana Block Grand tahun 2010;

13. Daftar hadir rapat pembahasan usulan pembangunan Desa Amboniki. 
- Bahwa benar untuk tanda tangan saksi ABDUL RASYID Terdakwa lakukan di hotel Telaga Damai Kota Kendari sedangkan tanda tangan saksi BASRAN dilakukan di rumah terdakwa di Kel. Arombu Kec. Unaaha Kab. Konawe;

- Bahwa benar terdakwa melakukan hal tersebut tidak ada yang menyuruh akan tetapi atas kemauan sendiri untuk membubuhkan tanda tangan BASRAN dan ABDUL RASYID;

Menimbang bahwa berdasarkan uraian, pengertian serta fakta hukum teresbut Majelis Hakim menyimpulkan bahwa Terdakwa membubuhkan tanda tangan saksi ABDULRASYID dan saksi BASRAN didalam proposal Dana Block Grand tahun 2010 untuk mempercepat proses pencairan dana tersebut dan hal tersebut tanpa diketahui oleh saksi ABDUL RASYID selaku Sekretaris Desa dan saksi SBASRAN selaku ketua LPM, perbuatan demikian digolongkan sebagai tindakan membuat surat palsu;

Menimbang bahwa berdasarkan kesimpulan tersebut, Majelis Hakim berpendapat unsur ini telah terpenuhi.

3. Unsur yang dapat menimbulkan sesuatu hak, perikatan, atau pembebasan hutang, atau yang diperuntukkan sebagai bukti daripada sesuatu hal, dengan maksud untuk memakai atau menyuruh orang lain memakai surat tersebut seolah-olah isinya benar dan tidak palsu, diancam jika pemakaian tersebut dapat menimbulkan kerugian, karena pemalsuan surat;

Menimbang, bahwa tidak semua surat dapat menjadi objek pemalsuan surat melainkan terbatas pada 4 macam sebagi unsur-unsur di atas;

Menimbang, bahwa mengingat elemen dalam unsur ke-3 tesebut tidak perlu semuanya terpenuhi;

Menimbang, bahwa untuk membuktikan unsur ini majelis hakim akan menguraikan fakta hukum sebagai berikut :

- Bahwa benar kejadiannya pada tanggal 27 Juni bertempat di Kel. Arombu Kec. Unaaha Kab. Konawe, terdakwa telah membubuhkan tanda tangan saksi ABDUL RASYID dan saksi BASRAN;

- Bahwa benar Terdakwa melakukan hal teresbut tidak ada yang menyuruh akan tetapi atas kemauan sendiri untuk melakukan pemalsuan tanda tangan;

- Bahwa benar terdakwa melakukan hal tersebut untuk mendapatkan serta untuk mengusulkan dana bantuan keuangan Block Grand tahun 2010 Desa Amboniki di kantor BPMD Sulawesi Tenggara ke rekening Desa Amboniki lewat Bank BPD Unaaha sebesar Rp. 50.000.000,-;

- Bahwa benar isi proposal tersebut yang kesemuannya ada tanda tangan saksi ABDUL RASYID dan saksi BASRAN berupa :

1. Permohonan bantuan dana Block Grand;

2. Lembaran daftar usulan kegiatan pembangunan Desa tahun anggaran 2010;

3. Lembaran rencana pembangunan jangka menengah Desa;

4. Lembaran alokasi bantuan Desa Amboniki; 
5. Lembaran daftar usulan kegiatan pembangunan Desa tahun anggaran 2010 tahap I Desa Amboniki;

6. Lembaran daftar ususlan kegiatan pembangunan Desa tahun anggaran 2010 tahap II Desa Amboniki;

7. Lembaran daftar ususlan kegiatan pembangunan Desa tahun anggaran 2010 tahap III Desa Amboniki;

8. Lembaran rencana alokasi bantuan dana bantuan keuangan Desa Kelurahan tahun 2010 tahap I Desa Amboniki;

9. Lembaran rencana alokasi bantuan dana bantuan keuangan Desa Kelurahan tahun 2010 tahap II Desa Amboniki;

10. Lembaran rencana alokasi bantuan dana bantuan keuangan Desa Kelurahan tahun 2010 tahap III Desa Amboniki;

11. Lembaran Berita Acara Musrembang Desa dalam menyusun RKP Desa Amboniki;

12. Lembaran daftar hadir musyawarah pembangunan Desa Amboniki tentang penggunaan Dana Block Grand tahun 2010;

13. Daftar hadir rapat pembahasan usulan pembangunan Desa Amboniki;

- Bahwa benar dana tersebut Terdakwa gunakan untuk pembangunan kantor Desa Amboniki dan sebagian digunakan untuk operasional seperni honor-honor Kepala Desa, Ketua LPM, BPD, Bendahara LPM, Sekretaris Desa, dan Kepala Dusun;

- Bahwa benar atas perbuatan terdakwa, saksi ABDUL RASYID dan saksi BASRAN sangat keberatan karena menyangkut uang negara dan jika dikemudian hari terjadi masalah atas dana tersebut maka saksi ABDUL RASYID dan saksi BASRAN akan terlibat di dalamnya;

Menimbang, bahwa berdasarkan fakta hukum di atas, Majelis Hakim menyimpulkan bahwa Terdakwa memalsukan tanda tangan saksi ABDULRASYID dan saksi BASRAN, dan Terdakwalah yang mengurus semua persyaratan proposal Dana Block Grand tahun 2010 tersebut hingga dana tersebut dicairkan di Bank BPD Unaaha, dengan demikian surat tersebut menimbulkan suatu hak untuk mencairkan dana Block Grand di Bank BPD Unaaha;

Menimbang, bahwa yang dimaksud dengan kerugian dalam pasal 263 ayat (1) KUHP adalah bukan hanya terbatas pada kerugian yang bersifat kebendaan melainkan juga yang tidak bersifat kebendaan seperti kepentingan masyarakat, arti kata "dapat" maksudnya tidak perlu kerugian itu betul-betul sudah ada, baru kemungkinan saja akan kerugian, itu sudah cukup;

Menimbang bahwa kemungkinan akan timbulnya suatu kerugian sudah dapat dikategorikan sebagai suatu dapat menimbulkan kerugian terlebih dalam lagi dalam keterangan terdakwa di persidangan bahwa memang terdakwa telah mengakui memalsukan tanda tangan saksi ABDUL RASYID dan saksi BASRAN apabila dihubungkan dengan keterangan saksi ABDUL RASYID dan saksi BASRAN yang menyatakan sangat keberatan karena menyangkut uang negara dan jika dikemudian hari terjadi masalah atas dana tersebut maka saksi ABDUL RASYID dan saksi BASRAN akan terlibat di dalamnya;

Menimbang bahwa selain kerugian tersebut di atas juga perbuatan tersebut dapat mendatangkan kerugian dalam 
arti luas yaitu merusak kepercayaan terhadap jabatan Kepala Desa terlebih nama baik terdakwa sendiri maupun keluarganya;

Menimbang bahwa berdasarkan uraian-uraian tersebut di atas, Majelis Hakim berpendapata bahwa unsur ini telah terpenuhi pada diri terdakwa;

Menimbang bahwa oleh karena seluruh unsur pasal 263 ayat (1) KUHP sebagaimana dalam dakwaan kesatu telah terpenuhi, maka terdakwa harus dinyatakan telah terbukti secara sah dan meyakinkan bersalah melakukan tindak pidana sebagaimana yang didakwakan dalam dakwaan kesatu Penuntut Umum;

Menimbang bahwa oleh karena selama pemeriksaan perkara berlangsung tidak ditemukannya adanya alasan pembenar maupun pemaaf pada diri maupun perbuatan Terdakwa sehingga sudah sepatutnya terdakwa dijatuhi pidana yang setimpal atas perbuatannya;

Menimbang bahwa pada hakikatnya penjatuhan pidana atas diri terdakwa bukan dimaksudkan sebagai pembalasan, akan tetapi bertujuan untuk pembinaan agar Terdakwa menyadari perbuatannya yang menyimpang sehingga mempunyai efek jera dan sebagai upaya prevensi bagi masyarakat umunya, agar tidak melakukan tindak pidana sebagaimana yang dilakukan oleh Terdakwa;

Menimbang bahwa tujuan pemidanaan didasarkan pada alasanalasan baik yang bersifat sosiologis, yuridis maupun ideologis yang kesemuannya saling berkaitan dan saling mempengaruhi dengan dilandasi oleh asumsi dasar bahwa tindak pidana merupakan gangguan terhadap keseimbangan, keselarasan dan keserasian dalam kehidupan masyarakat yang mengakibatkan kerusakan individual ataupun masyarakat, dengan demikian maka tujuan pemidanaan tersebut adalah untuk memperbaiki kerusakan individual dan sosial yang diakibatkan oleh tindak pidana;

Menimbang, bahwa selama pemeriksaan perkara ini terdakwa telah ditahan dalam kota Unaaha berdasarkan surat perintah atau penetapan penahanan yang sah, maka sudah sepatutnya penahanan kota tersebut dikurangkan seluruhnya dari pidana yang dijatuhkan;

Menimbang, bahwa mengenai barang bukti berupa :

- 1 (Satu) rangkap proposal bantuan Block Gran Desa Amboniki Kec. Unaaha Kab. Konawe;

Akan ditentukan dam amar putusan;

Menimbang, bahwa oleh karena Terdakwa dinyatakan bersalah dan dihukum maka terdakwa dibebankan membayar biaya perkara kepada negara yang besarnya ditentukan dalam amar putusan;

Menimbang, bahwa sebelum menjatuhkan putusan maka terlebih dahulu Majelis Hakim akan mempertimbangkan hal-hal yang memberatkan dan hal-hal yang meringankan sebagai berikut :

\section{Hal-hal yang memberatkan :}

- Terdakwa adalah seorang Kepala Desa yang seharusnya memberikan contoh yang baik kepada masyarakat serta menjadi suri tauladan;

\section{Hal-hal yang meringankan :}

- Terdakwa mengakui kesalahan dan menyesal;

- Terdakwa bersikap sopan selama persidangan; 
- Terdakwa mempunyai tanggungan keluarga;

- Tindakan itu dilakukan terdakwa semata-mata mempercepat proses administrasi pencairan;

- Terdakwa telah menggunakan Dana Block Grandn untuk kepentingan pembangunan Desa Amboniki.

Mengingat pasal 263 ayat (1) KUHP dan ketentuan pasal-pasal dari Undang-undang No. 1981 tentang KUHAP;

\section{MENGADILI}

1. Menyatakan Terdakwa ABDUL MUIS BIN KAEMEETO telah terbukti secara sah dan meyakinkan bersalah melakukan tindak pidana "pemalsuan surat";

2. Menjatuhkan pidana oleh karena itu kepada Terdakwa dengan pidana penjara selama 20 dua puluh hari;

3. Menetapkan masa penahanan yang telah dijalani Terdakwa dikurangkan seluruhnya dari lamanya pidana yang dijatuhkan;

4. Menetapkan barang bukti berupa :

1 satu rangkap proposal bantuan Block Grant Desa Amboniki Kec. Unaaha Kab. Konawe

\section{Tetap telampir dalam berkas perkara;}

5. Menetapkan terdakwa dibebankan untuk membayar biaya perkara sebesar Rp. 5.000,- lima ribu rupiah.

\section{Penutup}

- Kesimpulan

1. Pemalsuan surat merupakan suatu delik atau tindak pidana yang dilarang karena bertentangan dan melanggar apa yang telah tercantum dalam KUHP, yakni BUKU II BAB XII pasal 263 KUHP. Membuat surat palsu berbeda dengan memalsu surat. Membuat surat palsu yakni sebelum perbuatan tersebut dilaksanakan, surat tersebut belum ada. Baru kemudian dibuatkanlah suatu surat yang isinya baik sebagian maupun seluruhnya betrtolak belakang dengan yang sebenarnya. Sedangkan memalsu surat yakni sebelum melakukan perbuatannya, sudah ada suatu surat untuk dipalsukan yang dilakukan dengan cara bagaimanapun oleh si pemalsu surat, baik itu dengan cara menambah, mengurangi, maupun merubah isi daripada surat asli tersebut yang mengakibatkan surat asli itu menjadi palsu dan isinya bertentangan dengan isi yang sebenarnya. Memalsu surat dapat menimbulkan kerugian. Kata "dapat" maksudnya tidak perlu bahwa kerugian itu harus nyata atau benar-benar ada, baru kerugian itu sudah cukup untuk menjerat pelaku pemalsu surat itu.

2. Hakim dalam menjatuhkan putusan menganut beberapa teori antara lain : Sistem atau teori pembuktian berdasarkan Undang-undang secara positif, sistem atau teori pembuktian berdasarkan keyakinan hakim melulu, sistem atau teori pembuktian berdasar keyakinan hakim atas alasan yang logis, dan sistem atau teori pembuktian berdasarkan Undang-undang secara negatif. Dalam putusan Nomor 60/PID.B/2013/PN.Unh, sistem atau teori pembuktian yang digunakan oleh hakim adalah teori pembuktian berdasar Undang-undang secara negatif. Yakni hakim dalam menjatuhkan suatu putusan tidak hanya berdasar alat bukti yang sah, namun disertai juga dengan keyakinan hakim yang diperoleh dari alat-alat bukti tersebut.

Adapun akibat hukum dari suatu perbuatan pidana yang dilakukan oleh Kepala Desa ( seperti pemalsuan surat ) adalah hilangnya kpercayaan masyarakat terhadap Kepala Desanya dan tidak hanya itu 
nama baik kepala Desa sebagai terdakwa pemalsuan surat juga tercoreng begitu pula nama baik keluarga Kepala Desa tersebut pun juga iku tercoreng di kalangan masyarakat serta masyarakat yang namanya tercantum dalam surat palsu tersebut akan merasa sangat dirugikan karena mereka merasa tidak terlibat serta tidak tahu menahu akan isi serta adanya surat tersebut.

- Saran

1. Seorang Kepala Desa merupakan pemimpin dalam suatu lingkungan masyarakat Desa. Maka sudah sepatutnyalah menjadi suri tauladan yang baik bagi warga masyarakatnya, bukan menyalahgunakan wewenang atau kekuasaanya untuk melakukan suatu yang dilarang dalam norma hukum yang berlaku, namun dalam menjalankan tugasnya harus sesuai dengan norma hukum yang sudah ada.

2. Hakim seharusnya harus lebih memperhatikan serta mempertimbangkan tingkat kesalahan dari tindak pidana yang dilakukan oleh terdakwa ketika menjatuhkan hukuman dalam putusannya, terlebih lagi terdakwa adalah seorang Kepala Desa yang pasti paham akan norma hukum yang berlaku. Sehingga rasa keadilan bagi semua pihak dapat terpenuhi dan akan menimbulkan efek jera bagi terdakwa agar terdakwa tidak melakukan lagi tindakan yang melanggar aturan hukum yang berlaku.

\section{Daftar Pustaka}

Adami Chazawi dan Ardi Ferdian. Tindak Pidana Pemalsuan

(Tindak Pidana yang

Menyerang Kepentingan

Hukum Terhadap Kepercayaan

Masyarakat Mengenai

Kebenaran Isi Tulisan yang

Disampaikan).PenerbitPT

RajaGrafindo Persada. Jakarta.

Cetakan kedua, Tahun 2016.

Peter Mahmud Marzuki. Penelitian

Hukum. Penerbit

Prenadamedia Group. Jakarta.

Tahun 2016. Soerjono

Soekanto. Pengantar

Penelitiann Hukum. Penerbit

Universitas Indonesia (UI-

Press). Jakarta. Tahun 1986.

\section{PERUNDANG-UNDANGAN}

Kitab Undang-undang Hukum Pidana (KUHP).

\section{PUTUSAN}

Putusan Nomor 60/PID.B/2013/PN.unh. 